\title{
FACTORS AFFECTING WATER RETICULATION PROJECT DELIVERY IN OKIGWE ZONE IMO STATE, NIGERIA: AN EMPIRICAL PERSPECTIVE
}

\author{
Joy Okwuchi Chizitere Oguzie, Gregory Enyinnaya, Peter Paul Chukwuemezie Njoku
}

\author{
Department of Project \\ Management Technology, \\ Federal University of \\ Technology Owerri, \\ Owerri, Imo State, \\ Nigeria
}

Received: 25 April 2020 Revised: 26 May 2020 Accepted: 10 July 2020

\begin{abstract}
The study was conducted to examine the factors affecting water reticulation project delivery in Okigwe Zone of Imo State, Nigeria. Okigwe Zone was selected as the area of study because in spite of many water projects invested at the area, the accessibility of clean water is only $40.7 \%$ because of its topography. The study specifically ought to determine the various significant factors affecting water reticulation project delivery in the area. The study is a descriptive survey with questionnaire administered to 101 respondents who are professionals ranging from Architects, Quantity Surveyors, Civil/Water Engineers, Mechanical and Electrical Engineers. Descriptive statistical methods including frequencies and percentages were used as qualitative analytical techniques. For quantitative data, logistic regression model was used to determine the factors. The collected data were analysed using SPSS software version 21 . The study revealed that there is significant effect of the collective factors on water reticulation project delivery, factors such as topography, political will, infrastructural expansions, realistic scheduling systems etc. However it is of great importance to note that topography is a serious challenge to water reticulation project delivery in Okigwe Zone, such that it creates barriers to pipeline distribution networks and gravity flow in some areas of the zone. The study recommends that there is need to incorporate Artificial Intelligence and smart systems project monitoring to water reticulation projects in the area; and qualified project professionals and contractors with project management field experience should be used for water reticulation projects.
\end{abstract}

Keywords: Factors, projects, sustainability, water reticulation.

\section{INTRODUCTION}

The availability and quality of the water constitute an essential component of life. More than 3 billion inhabitants are projected to be living in water stressed nations by 2025 , and 14 countries slipping from water stress to scarcity (HDR, 2007). Combined with shifts induced by climate change, significantly disproportionate allocation of freshwater resources is now worse with respect to issues connected with sanitation and water-related problems (World Bank,
2010). Developing countries face a huge problem on how to supply their residents with healthy potable water. As the population in urban and rural areas increases, the demand for water is growing rapidly (Akpor, \& Muchie, 2011). Following this crisis, several stakeholders around the World have joined efforts to address the problem. For example, the World Bank has engaged 142 countries in lending for water (IEG, 2009). 579 projects $(31 \%)$ of the top 10 of those countries accounted for $56 \%$ of the overall world bank's

Corresponding author. Email: thesaintsintservices@gmail.com

ISSN 2560-4961 (online)

Copyright $\mathbb{C}$ 2020, The Authors. Published by IPMA Serbia.

This is an open access article under the CC BY-NC 4.0 license (https://creativecommons.org/licenses/bync/4.0/)

doi: $10.18485 /$ epmj.2020.10.1.4 
water infrastructure contribution (IEG, 2009). Lending for water increased by over 50 percent from 1997 to 2007(IEG, 2009).

Water reticulation systems are water distribution networks which have to collect water and then treated before distributing to the consumer (Hydro Serv, 2016). The supply of sufficient water quality and quantity was one of the most critical issues in the history of mankind. Many ancient civilizations were founded close bodies of water. The pressure to satisfy user demands also increased with rising populations. People began distributing water to their cities from other areas. For example, the Romans constructed aqueducts to provide their cities with water from distant sources. The water system currently comprises an infrastructure for water collection, treatment, storage and distribution (Adeosun, 2014).

Despite the worldwide Millennium Development Goals that achieved clean water by 2015 , close to $50 \%$ of states in Nigeria could not meet the aim and the sluggish speed of Nigeria's progress in this search may likely not achieve the 2030 sustainable development objective. The important or ongoing issue in Nigeria is not the absence of proposals and innovative technologies, nor the absence of infrastructure growth policies. The issue is the lack of continuity in enforcing regulations, a proper sustainability structure and quick transition of emerging technology and technical structures without impairing project efficiency. Presently, materials required in water reticulation projects have changed over time with new developed softwares designed in achieving best results on activities involved in water reticulation for timely project delivery but having desirable outputs that can stand the test of time is yet to be achieved.

The control of the efficiency, resources, energy, financing, environmental consequences and external factors such as the government and partners of the projects have, to a degree, been unpredictable, and reports have shown that governments and firms worldwide are investing large amounts of funds in projects as a consequence of project delays (Fabian, \& Amir, 2011). As such, the menace of failed and unsustainable projects needs to be checkmated through more viable research that can be implemented with ease.
Coming back to the issue project delivery of water reticulation projects, it is pertinent to note that in Imo State, the existing water network within Okigwe is old and most pipelines have exceeded their design lifecycle. It comprises of stainless steel, cast-iron, polyvinyl chloride (PVC) and asbestos cement pipe. Majority of the installations were done in the 1980/90's but no additional development has been carried out over time (Imo State Water Corporation, 2019). The Okigwes' internal water network is no more functioning and has numerous unregistered and unmetered connection points, as well as, undetected leaks. Each connection is associated with a monthly connection fee and administration challenges. Nowadays, water systems are commonly delivered through an infrastructure that consists of pipes which are typically constructed from materials such as plastic, metal or even concrete.

The system is built and prepared by town planners, municipal architects and contractors to find out all the specifics of the network before installation. The technical factors to be considered for the installation are: pipe size, location of the pipe, plans for future expansion, calculation of the probability of leaks, proximity of these systems to the fire departments (Adeosun, 2014).

A water reticulation system allows water to pass from the source to the user. An additional factor for preparing and constructing the system is considering the volume of water needed. The water is powered by energy and must conquer any opposition it faces as it switches heights or elevations. The factors mentioned previously and other project management factors will be paid attention to as they can affect operational cost. This necessitated this research work 'factors affecting water reticulation project delivery: a case study of Okigwe, Imo State.

\section{STATEMENT OF PROBLEM}

When the quality and quantity of water distribution is harnessed, most of the Millennium Development Goals (MDG's) targets can be met. Unfortunately, the population of Okigwe area has continued to increase rapidly while the water supply in the area has remained grossly inadequate to meet 
the daily needs of the people. The scarcity of water has greatly affected the production activities in the area and human services are being delayed. Despite the involvement of the Government, Non-Governmental Organization (NGO) and the private sector in water supply and sanitation projects, the quality and quantity of water supply has remained a problem to both rural and urban development. No significant attention has also been paid by the Okigwe Water Corporation to maintain and enhance the functionality of this water project and the pressure of demand for water resulting from this circumstance has been high. Consequently, there is that fear that the MDGs may be adversely affected if the water facilities are not in good condition.

In developed countries people are not allowed to build boreholes in their houses, although the supply of power is less prolific in the Republic of Ireland (McKibbin, 2014), almost everyone (over 99 percent) of the British population is supplied by public water supply. The water reticulation system is also pumped with steam in Canada. The main components of the system are pressure pumping stations, water storage reservoirs and the aid of pressure equalization systems and a system of pipes for water transport to users (Veil \& Quinn, 2008).

In England and Wales, about 1\% of the rest of the people doesn't receive public water for their home and rely rather on their private water supplies. Most of these occur in the farther, rural part of the country, but not exclusively (Drinking Water Inspectorate, 2018). The installation of this private borehole water supply is also controlled by local authorities who set a regulatory body known as, drinking water inspectorate (DWI) to conduct risk assessment before an individual can install private boreholes in their homes, drinking water inspectorate.

But in Nigeria, it is worrisome to note that majority of the water supply infrastructure, which is groundwater wells are constructed without proper consideration of sanitation such as provision of drainage systems for wastewater and spilt water. If provided is either inadequate or requires sensitization on sustainable cleaning. Whilst hazardous events range from insanitary/unhygienic activities and the introduction of substances that cannot be treated by the plant conventional treatment processes, it forms part of the pipe borne water issues. Consumers' pipe connections and to a lesser extent trunk pipe connections are mostly channeled through poorly sanitized gutter to individual households (Hayatu, \& Ibrahim, 2016).

Unlike developed countries, poor human and material management are some of the factors affecting water project and its effective delivery such as Nigeria. As a result of this, there is no network of pipes that is able to deliver water in full accordance with the designed system. Insufficient availability of standard engineers has also contributed to the problem of water reticulation project, as a factor in delivering of adequate water supply, while increasing head loss in the pipe network.

The factors that also need to be addressed which would affect water reticulation project delivery includes water vandalism, water theft, water leakage, service connection and communal standpipes, environmental condition, tariff, population number and distribution, technology, economic condition, environmental condition, preparation and implementation cycle, community management, cooperation of stakeholders, financial management. The knowledge of these factors, which would affect the effective delivery of water reticulation projects, when adequately considered, would lead to a positive impact towards dependable sustainability of the water supply projects. This study will peruse the mentioned factors in relation to Okigwe area of Imo state water reticulation project.

\section{PURPOSE OF THE STUDY}

The aim of this research work is to examine the factors affecting water reticulation projects in Okigwe Zone Imo State Nigeria. In other to achieve this aim, the following objectives are to be carried out:

i. To identify the common factors affecting water reticulation project delivery in Okigwe Zone.

ii. To analyze the collective effects of these factors on water reticulation project delivery. 
iii. To assess the individual effects of each of these factors on water reticulation project delivery.

iv. To rank these factors according the weight of their effects on water reticulation project delivery.

\section{RESEARCH HYPOTHESES}

In order to come to a conclusion as to what this research work is all about, the following hypotheses was drawn:

H01: There is no significant effect of the collective factors on water reticulation project delivery.

$\mathrm{HO} 2$ : There is no significant effect of each of the factors on water reticulation project delivery.

\section{SIGNIFICANCE OF STUDY}

This is to provide lasting solution to the problems facing water reticulation project delivery during the construction, management, maintenance and all activities involved in water reticulation project.

A large part of Okigwe Zone is semi-arid in which the area experience recurrent drought conditions (Ndukwe, 2011). Having this climatic condition, people living in this area experience the difficulties in getting clean water for domestic use. Despite the effort of the government and donors to address access to clean water problem, the success is very minimal. According to the information from the water corporation office, more than two hundred (200) government and donor funded projects have been initiated in Okigwe Zone (Imo State Water Corporation, 2019). Despite this heavy investment in clean water projects, still water shortage problem is high at Iringa District. According to Okigwe Zone economic profile (2013), accessibility of tap water (projects) at the district is $40.7 \%$ and other unsafe sources like wells, rivers, ponds, dams, lakes and streams contributes to the remaining 59.3\% (Irehie, Imaah, \& Gobo, 2019). The study findings are helpful to provide the ways forward that will help the government and the concerned community to arrive at the desired targets, but also the findings have to be used by the Local Government of Okigwe to refine the approaches that have been used for quite a long time in initiating clean water projects and water reticulation projects.

\section{SCOPE OF STUDY}

This research is on factors affecting water reticulation project delivery. It considered the existing factors affecting water projects in Nigeria and aims at improving the execution of water project as well. The area being perused as a case study was Okigwe water board, located at Uturu road opposite prison and Amuro village opposite market square, Imo state, Nigeria.

\section{RESEARCH METHODOLOGY}

Descriptive and correlative design was used in this research work, Descriptive survey is one in which a group of people or items are studied, by collecting and analyzing data from only a few people or items considered to be a representative of the entire group. Therefore, the descriptive survey is relevant to this study, because sample from the population was used and inference was made on the entire population. The population of this study refers to the totality of persons or organizations that has the capacity to undertake and implement water reticulation projects in Nigeria.

Due to the nature, size and cumbersome burden of getting at the entire population, the sample population of this study was delimited to and comprises of selected practitioners in Imo State Water Board and others in private practice. These include Architects, Quantity Surveyors, Civil Engineers, Geologists, Mechanical Engineers, Electrical Engineers, Construction Project Managers and Land Surveyors. Developers also formed part of the population. The main aim of choosing this type of population was to be able to get current and past information from people who have participated in the implementation of water reticulation projects and thus experienced the delivery challenges that the projects face.

The researcher adopted the purposive sampling method in this research work, due to the nature, size and cumbersome burden of getting at the entire population. A sample of 101 respondents was randomly drawn from the various population of the study using a purposive 
sampling procedure which includes Architects, Quantity Surveyors, Civil Engineers, Geologists, Mechanical Engineers, Electrical Engineers, Construction Project Managers and Land Surveyors. Purposive sampling procedure is when the researcher uses a convenient means of getting a sample from a given population.

The sample size was statistically determined using the formula of Taro Yamane (1964).

The formula is stated below

$$
n \frac{N}{1+N(e)^{2}}
$$

Where:

$$
\begin{aligned}
& \mathrm{N}=\text { Population size } \\
& \mathrm{e}=\text { Level of significance } \\
& \mathrm{n}=\text { sample size }
\end{aligned}
$$

Thus:

$$
\begin{gathered}
n=\frac{136}{1+136 \times(0.05)^{2}} \\
n=\frac{136}{1+136 \times 0.0025} \\
n=\frac{136}{1+1.34} \\
\frac{136}{1.34} \\
n=101
\end{gathered}
$$

The instrument used in data collection and measurement is questionnaire. The questionnaire was designed based on Likert five point scale. The structure of the scale from the respondent indicates their opinion which is any of the following:

Strongly disagree $=\mathrm{I}$ point, Disagree $=2$ points, Neutral $=3$ points, Agree $=4$ points, Strongly agree $=5$ points

These were designed and distributed to professionals at Imo State Water Board and others in private practice. The major aim for this questionnaire was to ensure that exact information is gotten as more people are reached, more opinions gotten. 101 questionnaires were distributed.
The data analysis techniques used for the test of hypothesis are multiple regression and correlation method. In economics and business, the natures of problem encountered in real life, are often expressed in more than two variables. All activities of man revolve around more than two variables. Multiple regressions approximate these real-life problems, where it measures the relationship existing between three or two variable. The multiple regressions help to understand the complexity of the interaction in business world.

Again, the aim of multiple regressions is to examine the nature of the relationship between a given dependent variable and two or more independent variables in a regression function. The concepts and techniques for analyzing the relationships between a dependent variable and several independent variables, are a straight forward extension of these involved in simple regression, the computations are however more complex and tedious, but with the help of electronic computer, becomes easy.

In multiple regression, as in simple regression, the model describing the relationship between dependent variables $\mathrm{y}$ and a set $\mathrm{k}$ independent variable $\mathrm{X} 1, \mathrm{X} 2, \ldots \ldots . \mathrm{XK}$ can be expressed as:

$$
\begin{gathered}
\mathrm{Y}=\mathrm{bo}+\mathrm{b} 1 \mathrm{X} 1+\mathrm{b} 2 \mathrm{X} 2+\mathrm{b} 3 \mathrm{X} 3+\mathrm{b} 4 \mathrm{X} 4 \\
+ \text { b5 } \mathrm{X} 5+\mathrm{b} 6 \mathrm{X} 6+\mathrm{b} 7 \mathrm{X} 7+\mathrm{b} 8 \mathrm{X} 8
\end{gathered}
$$

The test was conducted at 0.05 level of significance. A computer software based multiple regression analysis called statistical program for social science (SPSS) version 21 was used in the data analysis. The decision rule is thus if power of text ( $p$ - value) or significance is less than a, the null hypothesis is accepted, and the alternative hypothesis rejected, but if the other way round, therefore, the test is therefore said to be significant.

\section{Dependent Variable:}

$\mathrm{Y}=$ Water reticulation project delivery

\section{Independent Variables:}

$\mathrm{X} 1=$ Topography

$\mathrm{X} 2=$ Construction Design Changes.

$\mathrm{X} 3$ = Infrastructural Expansions

X4 $=$ Project Funding Levels

X5 = Project Cost Control Mechanisms

X6 $=$ Realistic Project Scheduling Systems

$\mathrm{X} 7=$ Community Involvement

X8 = Political Will 


\section{DATA ANALYSIS}

Response of distributed data

Out of hundred (101) copies of the questionnaire that was distributed, eighty nine (89) return.
Socio-Demographic Characteristic of the Respondents

Table 1: Gender of the respondents

\begin{tabular}{|l|c|c|}
\hline CHARACTERISTIC & FREQUENCY & PERCENTAGE (\%) \\
\hline Male & 74 & 83.1 \\
\hline Female & 15 & 16.9 \\
\hline Total & 89 & 100 \\
\hline
\end{tabular}

Source: Field data, 2020

The gender of the respondent shows that $83.1 \%$

(74) of the respondents are male while $16.9 \%$

(15) of the respondents are female. This shows that the majority of the respondents are male during the survey, this also goes a long way to prove that fact the male gender are the dominant gender in the Nigerian construction industry.

Table 2: Work Experience in Water Reticulation Project

\begin{tabular}{|l|c|c|}
\hline WORK EXPERIENCE & FREQUENCY & PERCENTAGE (\%) \\
\hline 1-5 years & 28 & 31.5 \\
\hline 6-10 years & 42 & 47.2 \\
& & 16.8 \\
\hline 11-15 years & 15 & 4.5 \\
\hline 16-20 years & 4 & - \\
\hline Above 20 & - & 100 \\
\hline TOTAL & 89 & \\
\hline
\end{tabular}

Source: Field data, 2020.

Table 3: Profession of Respondents

\begin{tabular}{|l|c|c|}
\hline PROFESSION & FREQUENCY & PERCENTAGE (\%) \\
\hline Civil/Structural Engineer & 37 & 41.6 \\
\hline Architect & 21 & 23.6 \\
\hline Quantity Surveyor & 16 & 17.9 \\
& & \\
\hline Electrical Engineer & 19 & 21.3 \\
\hline Mechanical Engineer & 18 & 20.2 \\
\hline Project Manager & 9 & 10.1 \\
\hline TOTAL & 89 & 100 \\
\hline
\end{tabular}

Source: Field data, 2020.

Table 4: Model summary

\begin{tabular}{|c|c|c|c|c|c|c|c|c|c|}
\hline \multirow[b]{2}{*}{ Model } & \multirow[b]{2}{*}{$\mathrm{R}$} & \multirow[b]{2}{*}{ R Square } & \multirow{2}{*}{$\begin{array}{l}\text { Adjusted } \\
\text { R Square }\end{array}$} & \multirow{2}{*}{$\begin{array}{l}\text { Std. Error } \\
\text { of the } \\
\text { Estimate }\end{array}$} & \multicolumn{5}{|c|}{ Change Statistics } \\
\hline & & & & & $\begin{array}{c}\text { R Square } \\
\text { Change }\end{array}$ & F Change & df1 & df 2 & Sig. F Change \\
\hline 1 & $.953^{\mathrm{a}}$ & .909 & .900 & .72614 & .909 & 99.951 & 8 & $80^{\mathrm{a}}$ & .000 \\
\hline
\end{tabular}

a. Predictors: (Constant), VAR00008, 0.953 which indicates a moderately positive VAR00005, VAR00006, VAR00001, relationship between the Dependent variable Y VAR00007, VAR00002, VAR00004, and the Independent variables (X1-X8). VAR00003

$R^{2}$, which is the coefficient of multiple

Considering the table 4 shown above, it reveals determination was observed to be $90.9 \%$. 
Table 5: ANOVA ${ }^{\mathrm{b}}$

\begin{tabular}{|ll|c|c|c|c|c|}
\hline Model & Sum of Squares & Df & Mean Square & F & Sig. \\
\hline \multirow{3}{*}{1} & Regression & 421.616 & 8 & 52.702 & 99.951 & $.000^{\mathrm{b}}$ \\
& Residual & 42.182 & 80 & .527 & & \\
& Total & 463.798 & 88 & & & \\
\hline
\end{tabular}

a. Dependent Variable: VAR00009

b. Predictors: (Constant), VAR00008, VAR00005, VAR00006, VAR00001, VAR00007, VAR00002, VAR00004, VAR00003

Considering the ANOVA analysis table displayed above, the result shows that it stands to determine whether there is a statically significant relationship between the variables stated. From table 5 above, it is clear that the significance level is 0.000 which is less than 0.05. This implies that there is statistical significant relationship between the variables.

Table 6: Coefficients ${ }^{\mathrm{a}}$ for $\mathrm{y}$

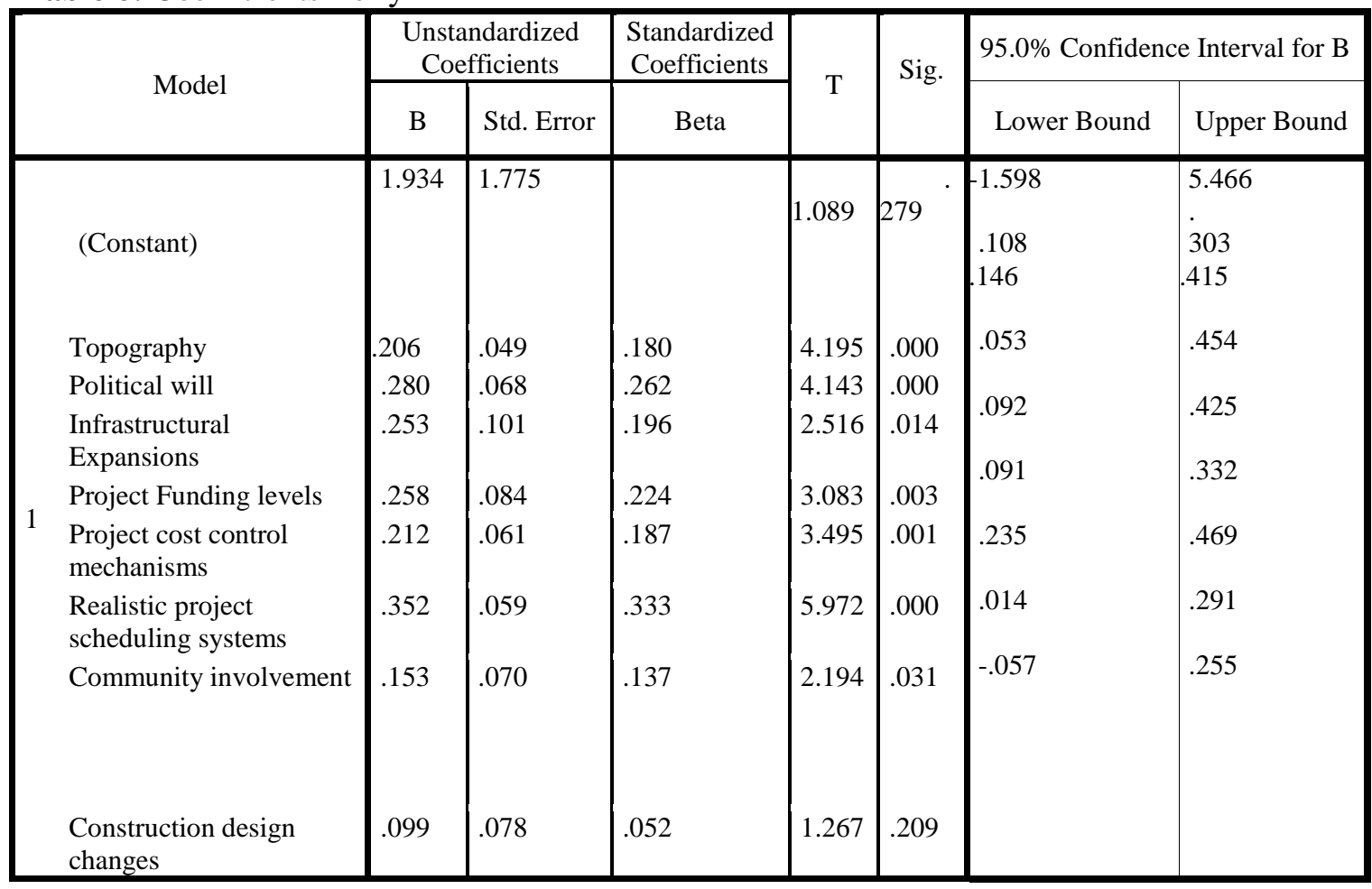

From table 6 , the model summary indicates that there is a very strong relationship between $\mathrm{Y}$ and $\mathrm{X}_{1}, \mathrm{X}_{2}, \mathrm{X}_{3}, \mathrm{X}_{4}, \mathrm{X}_{5}, \mathrm{X} 6, \mathrm{X} 7, \mathrm{X} 8$ with the coefficient correlation $\mathrm{R}=0.953(95.3 \%)$ and coefficient of determination $\mathrm{R}^{2} 0.909$ (90.9\%).

From table 6, all the factors except construction design changes are significant. It has significance value of 0.209 which is above 0.05 level of significance.

Table above shows the coefficient of each of the explanatory variables $\mathrm{X}_{1}-\mathrm{X}_{8}$, which are found to be $0.000,0.000,0.014,0.003,0.001$,
$0.000,0.031$ and 0.209 respectively. This result is a further explanation on the ANOVA in table 5. It reveals that $X_{1}-X_{7}$ are all variables that are responsible for that significance of the model.

Hence, the model is thus summarised in the equation below:

$$
\begin{gathered}
\mathrm{Y}=1.934+0.206 \mathrm{X} 1+0.280 \times 2+0.253 \times 3+0.258 \\
\mathrm{X} 4+0.212 \mathrm{X} 5+0.352 \mathrm{X} 6+0.153 \times 7+0.09984
\end{gathered}
$$




\section{Ranking of Results}

Table 7: The Variables are Ranked Based on their Significance Value and Mean Value

\begin{tabular}{|l|c|c|c|}
\hline Variables & Sig Value & Mean Value & Ranked \\
\hline $\mathrm{X}_{1}$ (Topography) & 0.000 & 4.195 & $2^{\text {nd }}$ \\
\hline $\mathrm{X}_{2}$ (Political Will) & 0.000 & 4.143 & $3^{\text {rd }}$ \\
\hline $\mathrm{X}_{3}$ (Infrastructural Expansions) & 0.014 & 2.516 & $6^{\text {th }}$ \\
\hline $\mathrm{X}_{4}$ (Project Funding Levels) & 0.003 & 3.083 & $5^{\text {th }}$ \\
\hline $\begin{array}{l}\mathrm{X}_{5} \text { (Project Cost Control } \\
\text { Mechanism) }\end{array}$ & 0.001 & 3.495 & $4^{\text {th }}$ \\
\hline $\begin{array}{l}\mathrm{X}_{6} \text { (Realistic Project } \\
\text { Scheduling) }\end{array}$ & 0.000 & 5.972 & $1^{\text {st }}$ \\
\hline $\mathrm{X}_{7}$ (Community Involvement) & 0.031 & 2.194 & $7^{\text {th }}$ \\
\hline $\begin{array}{l}\mathrm{X}_{8} \text { (Construction Design } \\
\text { Changes) }\end{array}$ & 0.209 & 1.267 & $8^{\text {th }}$ \\
\hline
\end{tabular}

\section{TEST OF HYPOTHESIS}

\section{Hypothesis One}

HO1: There is no significant effect of the collective factors on water reticulation project delivery.

From table 6 , the power of test, $\mathrm{p}$ - value (sig) $\mathrm{F}$ sig change value $=0.000<\alpha=0.05$. Therefore, the test is said to be significant. The study concludes that there is a significant effect of the collective factors on water reticulation project delivery in Okigwe Zone.

\section{Hypothesis Two}

HO2: There is no significant effect of each of the factors on water reticulation project delivery.

From table 6 , the significance value of each of the factors are significant except for variable 8 (construction design changes) which has a value of 0.203 .

It is pertinent to conclude that there is significant effect of each of the factors on water reticulation project delivery.

\section{DISCUSSION OF RESULTS}

The discussion of the test shows that there is significant effect of the collective factors on water reticulation project delivery. This depicts that all the identified factors holistically affects water reticulation projects in Okigwe Zone, Imo State Nigeria. The reticulation project professionals ranging from project managers to other construction professionals unanimously from their responses reflected in the ANOVA table, concurred that all the identified factors put together affects water reticulation project delivery. This shows that an increase in activities of the factors collectively spurs a significant change in the delivery of water reticulation projects in the Zone.

Furthermore, from the analysis of the study, it can be seen that the explained variable, Water Reticulation Project Delivery (Y), was observed to possess some measures of relationship with the explanatory variables. Water Reticulation Project Delivery (Y) has a high positive relationship $(\mathrm{R}=0.953)$ with the explanatory variables $\left(\mathrm{X}_{1}-\mathrm{X}_{8}\right)$. Also, the coefficient of determination value of $90.9 \%$ was determined. This statistics explains the variation in Water Reticulation Project Delivery (Y) by the explanatory variables. This implies that $9.1 \%$ variation in Water Reticulation Project Delivery (Y) is left unaccounted for by the explanatory variables, which could be termed as error in the model. Also, the adjusted coefficient of determination value of $90.0 \%$ was determined, meaning that $10.0 \%$ of the variation in Water Reticulation Project Delivery (Y) is explained by the explanatory variables. Hence, the F-statistics with the value of 99.951 and probability of 0.000 indicates that the independent variables are jointly significant in explaining the variation in the dependent variable Water Reticulation Project Delivery (Y).

Looking at the model for individual contributions of the independent variables, all the factors showed a positive significant relationship with Sustainability of Public Infrastructure $(\mathrm{Y})$ except construction design changes (X8) depicting that $1 \%$ increase in $\mathrm{X}_{1}$, $\mathrm{X}_{2}, \mathrm{X}_{3}, \mathrm{X}_{4}, \mathrm{X}_{5}, \mathrm{X}_{6}, \mathrm{X}_{7}, \mathrm{X}_{8}$ will cause $0.206 \%$, $0.280 \%, 0.253 \%, 0.258 \%, 0.212 \%, 0.352 \%$, $0.153 \%$ or $0.0998 \%$ increase in Y. 
The results in a clearer light unveils that realistic project scheduling system (X6) affects water reticulation project delivery the most followed by topography (X1), political will (X2), project cost mechanism (X5), project funding levels (X4) etc. respectively. However it is of great importance to note that topography is a serious challenge to water reticulation project delivery in Okigwe Zone, such that it creates barriers to pipeline distribution networks and gravity flow in some areas of the zone. Also infrastructural expansions like unplanned dualization of Okigwe town roads which did not take into cognizance the existing pipeline grids, damaged many existing pipelines, thereby posing a challenge to water reticulation project delivery in the area. The result according to project managers' experts' opinion showed that there is need for the use of earned value system of project cost management if construction projects has to have efficient project cost control. Finally, political will and community involvement plays a big role to water reticulation project delivery in Okigwe Zone.

\section{CONCLUSIONS}

Since the 1950s most of the work in project management has focused on project scheduling problems, assuming that the development of better scheduling techniques would result in better management and thus the successful completion of projects. However, there are many factors outside the control of management which could determine the success or failure of a project especially a water reticulation project. In the literature, these factors are referred to as critical success/failure factors and only a few studies have been done to assess, clarify, or analyse these factors. Most of the early studies in the area focused on other projects but not water reticulation projects.

Success is desired in everyday life, in business activities and in projects. Given the high rate of projects that fail reaching their objectives or creating the wanted effects, researches that approach the topic of success bring positive inputs both to literature and to practice. Relating literature reviews with studies that capture the realities of business environments increase the usefulness of the results. The study reveals that there are direct which affects water reticulation project delivery especially in the study area. For instance, factors like topography, infrastructural expansions, political will etc, while the indirect factors though not mentioned in this study include setting of water prices, poor quality of service delivery, absence of payment receipt for the service, long distance from household to the main water source and existence of alternative water sources. Progress toward attaining sustainability of water and projects will require a shift from singularly focusing on expanding infrastructure in areas without service, to dually concentrating on achieving long-term functionality goals through improved operation and maintenance of existing supplies.

\section{RECOMMENDATIONS}

The following recommendations were drawn from the findings of the study:

1. The increasing rate of water project failure especially in the rural areas should be addressed in order to achieve reliable supply of safe and clean water to the rural populations. Local governments, donors and communities should make sure that capacity buildings for project management to the community and water user association members become a sustainable process for the attainment of water project sustainability.

2. Community participation is a useful means for achieving sustainable development in rural areas. In order to achieve sustainable development, interactive and self- mobilization types of participation are recommended whereby people are actively involved in all stages of project identification, planning, implementation, monitoring and evaluation for sustainable development. In this case the central government, Local governments and donors when planning to initiate a project for the community, they should seek for a really participation of all beneficiaries.

3. Proper communication should be ensured between water users and their leaders so as to clarify or rectify any problem happening at early times. There should be clear articulation of the roles for each actor in water 
management at the study area. Private sector should also be actively involved in the form of public-private partnership so that they become part and owners of the water management at the study area.

4. Regular maintenance of rural water projects is very important in achieving sustainability. Regular maintenance is facilitated by regular training of the Water board field workers and village technicians. Therefore, it is recommended that Water board field workers and village technicians should be trained on how to handle minor and major maintenance instead of depending on maintenance workers from outside.

5. There is need to incorporate Artificial Intelligence and smart systems project monitoring to water reticulation projects in the area.

6. Qualified project professionals and contractors with project management field experience should be used for water reticulation projects.

\section{REFERENCES}

Adeosun, O. O. (2014). Water Distribution Systems Challenges and Solutions. Water Online. www.wateronline.com

Akpor, O. B., \& Muchie, M. (2011). Challenges in meeting the MDGs: The Nigerian Drinking Water Supply and Distribution Sector. Journal of Environmental Science and Technology. 4(5), pp. 480-489.

Drinking Water Inspectorate (2018). Chief Inspectorate of Water Report, DWI Annual Report, 2018. London, UK.

Fabian, C., \& Amir, A. (2011). The ChadCameroon Pipeline Project--Assessing the World Bank's Failed Experiment to Direct Oil Revenues towards the Poor. The Law and Development Review. De Gruyter. $4(1)$, pp. 32-65.

Hayatu, J. A., \& Ibrahim, U. M. (2016). The Influence of Drinking Water Quality on Health and Food Security in Taraba State, Nigeria. European Journal of Earth and Environment. 3(2), pp. 1-16.

Human Development Report (HDR). (2007). Beyond Scarcity: Power, Poverty and the
Global Water Crisis. United Nations Development Programme, New York.

Hydro Serv. (2016). Water Reticulation. Available at: www.hydroserv.com.au

Imo State Water Corporation. (2019). Water Policy for USAID Projects in Imo State. Government Press, Owerri.

Independent Evaluation Group. (2009). Water and Development: An Evaluation of World Bank Support, 1997-2007. Report.

Irehie, C., Imaah, N., \& Gobo, A. (2019). Building Orientation Pattern for Microclimate Comfort along Slopes in Okigwe Zone, Southeastern Nigeria. Journal of Architecture and Construction. 2(4), pp. 1-13.

McKibbin, D. (2014). An examination of business models within the Water and Sewerage Industry in the UK and Republic of Ireland. Northern Ireland Assembly Research and Information Service Research Paper. NIAR 711-13, Paper 105/14.

Ndukwe, C. O. (2011). Droughts and Agriculture in the Semi-Arid Zone of Okigwe, Imo State, Nigeria. Nigerian Journal of Water Technology. 12(1).

RWSN. (2010). Sustainable Rural Water Supplies. Rural Water Supply Network, St. Gallen.

Veil, J., \& Quinn, J. (2008). Water Issues Associated with Heavy Oil Production. Argonne National Laboratory.

Water Aid. (2014). Addressing the Sustainability Crisis: Lessons from research on managing rural water projects. Available at: www.wateraid.org/.../sustainabilitycrisis-rural-water-managem

WHO. (2011). Guidelines for Drinking-Water Quality, 4th ed., WHO. Press Pp 22.

WHO and UNICEF (World Health Organization/United Nations Children's Fund). (2014). Progress on drinking water and sanitation: 2014 Update. New York, WHO/UNICEF Joint Monitoring Programme for Water Supply and Sanitation.

World Bank. (2010). An Evaluation of World Bank Support, 1997-2007: Water and Development. Washington DC. Available at: www. copyright.com.

Yamane, T. (1964). An Introductory Analysis. New York: Harper and Row. 